\title{
MUTATION ANALYSIS OF DJ-1 GENE IN VIETNAMESE PARKINSON'S DISEASE PATIENTS
}

\author{
Ho Truong Giang ${ }^{1}$, Nguyen Duc Hieu ${ }^{2}$, Nguyen Thi Hoai Thu ${ }^{2}$, Vu Xuan Nghia ${ }^{1}$, Vo Thi Bich Thuy ${ }^{2, 凶}$ \\ ${ }^{1}$ Military Medical University, Ministry of National Defense \\ ${ }^{2}$ Institute of Genome Research, Vietnam Academy of Science and Technology
}

${ }^{\square}$ To whom correspondence should be addressed. E-mail: thuytbvo@igr.ac.vn

Received: 22.11 .2017

Accepted: 28.12.2017

\section{SUMMARY}

\begin{abstract}
Parkinson's disease (PD) is a degenerative condition of the brain of uncertain cause that mainly affects older people. Shaking is a distinctive feature of the disease, but slowness, poverty of movement and stiffness interfere with everyday life. A large number of known pathogenic mutations of genes related to PD have been identified. The $D J-1$ gene, one of PARK genes, is considered as the primary cause of PD in different populations. The analysis of mutation frequency of the $D J-1$ gene in Vietnamese PD patients is necessary to clarify the pathogenic associations of PD with the $D J-1$ gene and to understand the pathogenesis and genetic mechanisms of PD. In this study, genomic DNA was extracted from peripheral blood of 30 PD patients (mean age $64.11 \pm 7.31$ years) and 20 controls and directed Sanger sequencing of one fragment of $D J-1$ gene, containing the introns 4 and 5 as well as exon 5 . The obtained results showed that there were 13 heterozygous or homozygous point mutations in introns 4 and 5. The late-onset sporadic PD (LOPD) patient carried a single homozygous mutation in intron 5 (IVS5 $+31 \mathrm{G}>\mathrm{A}$ ), and others had a heterozygous mutation, all of unknown significance. Moreover, both the Ala86Glu and Gly95Leu mutations in exon 5 were present in one LOPD patient suggesting possible change of functional protein. Analysis of these mutations were shown the nonsynonymous and uncertain significant mutation, therefore they may not be related to pathogenic mutations of PD. Further research is needed to study the contribution of the novel found mutation in other PARK genes to the pathogenesis of Vietnamese PD patients.
\end{abstract}

Keywords: DJ-1 gene, exon 5, PARK loci, Parkinson's disease, Sanger sequencing

\section{INTRODUCTION}

At that moment, epidemiologic studies have highlighted the effects of interactions between genetic and environmental factors on the clinical signs of PD. An increasing number of genetic loci and numerous risk factors have been discovered, starting from the familiar genes responsible for the Mendelian inherited forms, such as the autosomal dominant genes ( $S N C A$, $L R R K 2, V P S 35, G B A)$, the typical recessive (PARK2, $P I N K 1, \quad P A R K 7)$, the atypical recessive ones (ATP13A2, PLA2G6, FBXO7) (Klein, Westenberger, 2012) and other risk genes recently linked to the disease such as GBA (Sidransky et al., 2009) and GCH1 (Kefalopoulou et al., 2014).

$P A R K 7$ was the third gene identified in 2001 as responsible of PD. It encodes a conserved multifunctional protein belonging to the peptidase
C56 family (also called $D J-1$ ). The $D J-1$ gene contains 8 exons distributed over $24 \mathrm{~kb}$. It was originally identified and described as an oncogene and the 189 amino acid protein is highly conserved across species (Bonifati et al., 2003). DJ-1 appears to have several functions within the cell, in human and murine cell lines, $D J-1$ has been identified as a hydroperoxide-responsive, which suggests a function as an antioxidant protein (Mitsumoto, Nakagawa, 2001). Originally recognized as a c-myc interacting protein (Rakshit et al., 2014), DJ-1 has been identified as an infertility related protein (Honbou et al., 2003; Saito et al., 2014), associated with RNA stabilization (Malgieri, Eliezer, 2008; Matsuda et al., 2017) and shown to convert to a more acidic form under conditions of oxidative stress (Bjorkblom et al., 2014; Mitsumoto, Nakagawa, 2001; Yanagida et al., 2009). Oxidative modifications of $D J-1$ have been implicated in the mechanisms of neuronal death 
and the pathogenesis of PD. It has been suggested that $D J-1$ protect neurons against oxidative stress by acting as a redox-dependent chaperone. The protein is normally found in the cytoplasm and oxidative stress promotes relocation to mitochondria where it protects against mitochondrial toxins (Lin et al., 2012; Zhang et al., 2005). Mutations in the DJ-1 gene have recently been shown to cause autosomal recessive PD (Healy et al., 2004). Moreover, the loss of function of $D J-1$ caused by mutations in $D J-1$ causes a form of familial PD (Chen et al., 2017). It was recently shown that the DJ-1 protein is degraded by the ubiquitin proteasome system and that this process is expedited for the PD (Bonifati et al., 2003). However, the mechanism by which loss of DJ-1 causes Parkinsonism is unclear currently.

\section{MATERIALS AND METHODS}

\section{Patient selection}

Thirty PD patients were recruited from the Military Central Hospital (Table 1). Standard neurological clinical examination of all patients was performed before participation. The diagnosis of PD was based on published criteria (Clarke et al., 2016). This study was approved by the Medical Ethics Committee of Military Medical University and conformed to the ethical standards of the Helsinki Declaration. All PD patients and volunteers provided written informed consent.

Table 1. General Characteristics of Vietnamese PD patients.

\begin{tabular}{ll}
\hline General Characteristics & PD patients $(\mathbf{n}=\mathbf{3 0})$ \\
\hline $\begin{array}{l}\text { Age at time of study median, } \\
\text { year }\end{array}$ & $65.5 \pm 7.3$ \\
Age at male median, year & $64.7 \pm 7.07$ \\
Age at female median, year & $63.6 \pm 7.55$ \\
Male sex, $n$ (frequency) & $21 / 30(70 \%)$ \\
Female sex, $n$ (frequency) & $9 / 30(30 \%)$ \\
\hline
\end{tabular}

\section{Total DNA extraction, PCR and sequencing}

A blood sample was collected from a peripheral vein of each patient using venipuncture, and genomic DNA was extracted according to the kit protocol (GeneJET Genomic DNA purification, Thermo Science, USA). One coding exon of the $D J-1$ gene was amplified by polymerase chain reaction (PCR) under the following conditions: denaturation at $94^{\circ} \mathrm{C}$ for 15 minutes, followed by 35 cycles of denaturation at $94^{\circ} \mathrm{C}$, annealing at $63^{\circ} \mathrm{C}$ and elongation at $72^{\circ} \mathrm{C}$ for 30 seconds each, and a final elongation step of 7 minutes at $72^{\circ} \mathrm{C}$. PCR was carried out in a final volume of $50 \mu 1$ including $2.5 \mathrm{mM} \mathrm{MgCl}, 0.2 \mathrm{mM}$ deoxynucleotide triphosphate, $0.5 \mu \mathrm{M}$ forward and reverse primer (forward: 5'-AAATAGGTCAGAGAGCTTGTGG-3' and reverse: 5'-TCAAACCATCGAATGAAAGG-3'), 1 U Taq polymerase (Promega- M8305, USA), and 10 ng of DNA. The quality of the PCR products was analyzed by $2 \%$ agarose gel electrophoresis with size of PCR product ca. $260 \mathrm{bp}$.

Purification of the amplified fragment was performed by using GeneJET PCR purification kit (Thermo Science, USA). For sequence analysis, bidirectional dideoxy chain terminator sequencing was carried out according to the manufacturers' instructions (BigDye, Applied Biosystems, UK) and the products were electrophoresed on an ABI 3500 Genetic Analyzer (Applied Biosystems, CA, USA).

\section{Statistical Analysis}

A sequence of human DJ-1 gene (NC_000001.11) in NCBI GenBank was used as reference sequence. The exon and protein sequences of $D J-1$ were vailable in Ensemble database (http://www.ensembl.org). These sequences used to identify the location of exon 5. DNA sequences of both PD patients and controls were translated using BioEdit Software to get protein sequences. A multiple sequenced alignment of genes and proteins was perform by using ClustalW tool of BioEdit software. Alignment result was analyzed to find down the nucleotide and amino acid substitution.

\section{RESULTS AND DISCUSSION}

In this study, we identified 18 known variant mutations among 30 PD patients (60\%) (see Table 2). There was only one male PD patient carried 3 mutation positions, including exon 5 and introns 4 and 5. Parallel mutations in introns 4 and 5 were 6 cases $(20 \%)$, and another single mutation in the intron 4 (6 PD patients) or intron 5 (5 PD patients). A large number of known mutations related to $\mathrm{PD}$ have been identified. In particular, DJ-1 mutations appear to be considerably frequent in our population, suggesting a strong genetic and/ or environmental factors influence. Further research is needed to verify the contribution of the novel found mutation in the pathogenesis of Vietnamese PD. 
Table 2. Patient information with PD for the $D J-1$ mutation in exon 5 and intron 4, 5 .

\begin{tabular}{llllll}
\hline No & ID & Name & Sex & Age at sampling & Position of mutation \\
\hline 1 & 6 E5 & Nguyen Trung K & Male & 67 & Exon 5, Intron 4, Intron 5 \\
2 & 7 E5 & Nguyen Viet H & Male & 50 & Intron 4, Intron 5 \\
3 & $8 E 5$ & Hoang Van P & Male & 60 & Intron 4 \\
4 & $9 E 5$ & Nguyen Duy M & Male & 75 & Intron 5 \\
5 & $10 E 5$ & Ho Minh A & Male & 60 & Intron 5 \\
6 & $12 E 5$ & Hoang H & Male & 74 & Intron 4, Intron 5 \\
7 & 14E5 & Quan Van T & Male & 61 & Intron 4 \\
8 & $16 E 5$ & Le Huu K & Male & 71 & Intron 4 \\
9 & $17 E 5$ & Le Van H & Male & 69 & Intron 4 \\
10 & $18 E 5$ & Nguyen Dang D & Male & 78 & Intron 4 \\
11 & $19 E 5$ & Nguyen Van Q & Male & 57 & Intron 4, Intron 5 \\
12 & $22 E 5$ & Trinh Huu L & Male & 57 & Intron 4 \\
13 & $23 E 5$ & Nguyen Dac C & Male & 60 & Intron 4, Intron 5 \\
14 & $25 E 5$ & Trieu Thi T & Female & 69 & Intron 5 5 \\
15 & $27 E 5$ & Nguyen Minh N & Female & 74 & Intron 4, Intron 5 \\
16 & $28 E 5$ & Nguyen Van T & Male & 69 & Intron 5 \\
17 & $29 E 5$ & Nguyen Anh S & Male & 68 & Intron 4, Intron 5 \\
18 & 30E5 & Pham Hong N & Male & 67 & \\
\hline
\end{tabular}

Table 3. Sequence alterations on exon 5 and intron 4 and 5 of $D J-1$ gene.

\begin{tabular}{|c|c|c|c|c|c|c|c|c|c|c|c|}
\hline $\begin{array}{l}\text { Number } \\
\text { of PD } \\
\text { mutation }\end{array}$ & $\begin{array}{l}\text { Reference } \\
\text { sequence }\end{array}$ & Allele 1 & Allele 2 & $\begin{array}{l}\text { Amino } \\
\text { Acid } 1\end{array}$ & $\begin{array}{l}\text { Amino } \\
\text { Acid } 2\end{array}$ & $\begin{array}{l}\text { cDNA } \\
\text { position }\end{array}$ & $\begin{array}{l}\text { Protein } \\
\text { position }\end{array}$ & $\begin{array}{l}\text { Intron } \\
\text { position }\end{array}$ & $\begin{array}{l}\text { Mutation } \\
\text { alternative }\end{array}$ & $\begin{array}{l}\text { Amino } \\
\text { acid } \\
\text { change }\end{array}$ & $\begin{array}{l}\text { Mutation } \\
\text { description }\end{array}$ \\
\hline 4 & T & T & C & & & & & -49 & IVS4-49T >C & & Heterozygous \\
\hline 1 & A & A & C & & & & & -38 & IVS4-38A>C & & Heterozygous \\
\hline 1 & $T$ & $\mathrm{~T}$ & G & & & & & -24 & IVS4-24T>G & & Heterozygous \\
\hline 1 & $G$ & G & $\mathrm{T}$ & & & & & -16 & IVS4-16G>T & & Heterozygous \\
\hline 1 & $T$ & $T$ & C & & & & & -15 & IVS4-15T>C & & Heterozygous \\
\hline 1 & $T$ & $\mathrm{~T}$ & C & & & & & -14 & IVS4-14T>C & & Heterozygous \\
\hline 2 & $T$ & $\mathrm{~T}$ & C & & & & & -13 & IVS4-13T>C & & Heterozygous \\
\hline 3 & $\mathrm{~T}$ & $\mathrm{~T}$ & C & & & & & -12 & IVS4-12T>C & & Heterozygous \\
\hline 1 & A & A & G & & & & & -5 & IVS4-5A>G & & Heterozygous \\
\hline 1 & C & C & G & & & & & -4 & IVS4-4C>G & & Heterozygous \\
\hline 7 & G & A & A & & & & & 31 & IVS5+31G>A & & Homozygous \\
\hline 1 & A & A & $\mathrm{T}$ & & & & & 34 & IVS5+34A>T & & Heterozygous \\
\hline 7 & G & G & $\mathrm{T}$ & & & & & 42 & IVS5+42G>T & & Heterozygous \\
\hline 1 & C & C & G & A & G & 257 & 86 & & $\begin{array}{l}\text { c. } 257 \mathrm{C}>\mathrm{G} \\
\text { p.A86G }\end{array}$ & Ala $>$ Glu & Heterozygous \\
\hline 1 & A & A & T & Q & L & 284 & 95 & & $\begin{array}{l}\text { c. } 284 \mathrm{~A}>\mathrm{T} \\
\text { p.G95L }\end{array}$ & Gly>Leu & Heterozygous \\
\hline
\end{tabular}


We sequenced exon 5 and intron 4 and 5 of $D J-1$ in 30 PD patients with onset range of over 50 years old in an attempt to identify mutations causing disease and gain further insight into the role of $D J-1$ in $\mathrm{PD}$, see table 3.

Here, we have searched for mutation in the intron border of exon 5 (see Table 3 and Figure 1). We detected a 13 mutation points in intron 4 and 5 . In which, 10 heterozygous mutations in intron 4 (e.g., IVS4-49T $>C$ in 4 PD patients, IVS4-38A $>C$ in 1 PD patient, IVS4-24T $>$ G in 1 PD patient, IVS4$16 \mathrm{G}>\mathrm{T}$ in $1 \mathrm{PD}$ patient, IVS4-15T $>\mathrm{C}$ in $1 \mathrm{PD}$ patient, IVS4-14T $>\mathrm{C}$ in $1 \mathrm{PD}$ patient, IVS4-13T $>\mathrm{C}$ in $2 \mathrm{PD}$ patients, IVS4-12T $>\mathrm{C}$ in $3 \mathrm{PD}$ patients,
IVS4-5A $>\mathrm{G}$ in $1 \mathrm{PD}$ patient, and IVS4-4C $>\mathrm{G}$ in 1 $\mathrm{PD}$ patient); 2 heterozygous mutations (e.g., IVS5+34A $>\mathrm{T}$ in $1 \mathrm{PD}$ patient and IVS5 $+42 \mathrm{G}>\mathrm{T}$ in 7 $\mathrm{PD}$ patients) and 1 homozygous mutation (e.g., IVS5+31G $>A$ in 7 PD patients) in intron 5, but no mutation carries were identified among 20 controls. There are a few possible outcomes of these mutations; it could influence the effectiveness of intron splicing, it could lead to the accumulation of unspliced pre-RNA in the nucleus and be subject to rapid degradation, or it may result in the activation of an alternative cryptic splice site affecting the coding region of the gene. In all cases, this variant is predicted to have drastic consequences on $D J-1$ gene and would to an aberrant transcript (Berget, 1995).

\section{A I}

\section{$31 \mathrm{E} 5$}

$6 \mathrm{E} 5$

$7 \mathrm{E} 5$

$8 \mathrm{E} 5$

$12 \mathrm{E} 5$

$14 \mathrm{E} 5$

$16 \mathrm{E} 5$

$17 \mathrm{E} 5$

$18 \mathrm{E} 5$

$19 \mathrm{E} 5$

22E5

23E5

$28 \mathrm{E} 5$

$30 \mathrm{E} 5$

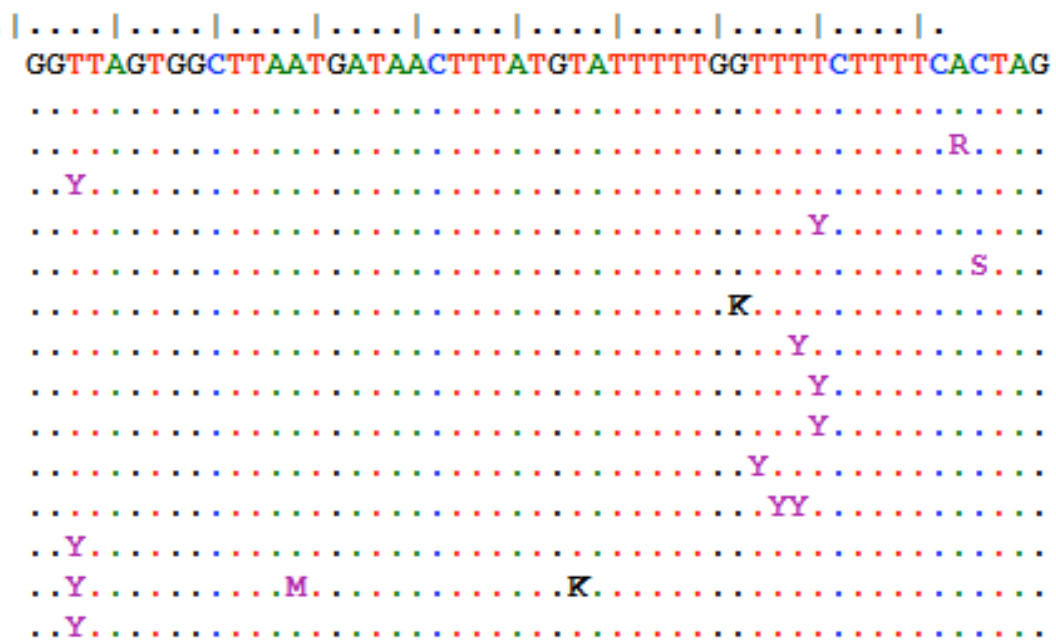

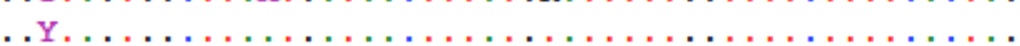

\section{B}

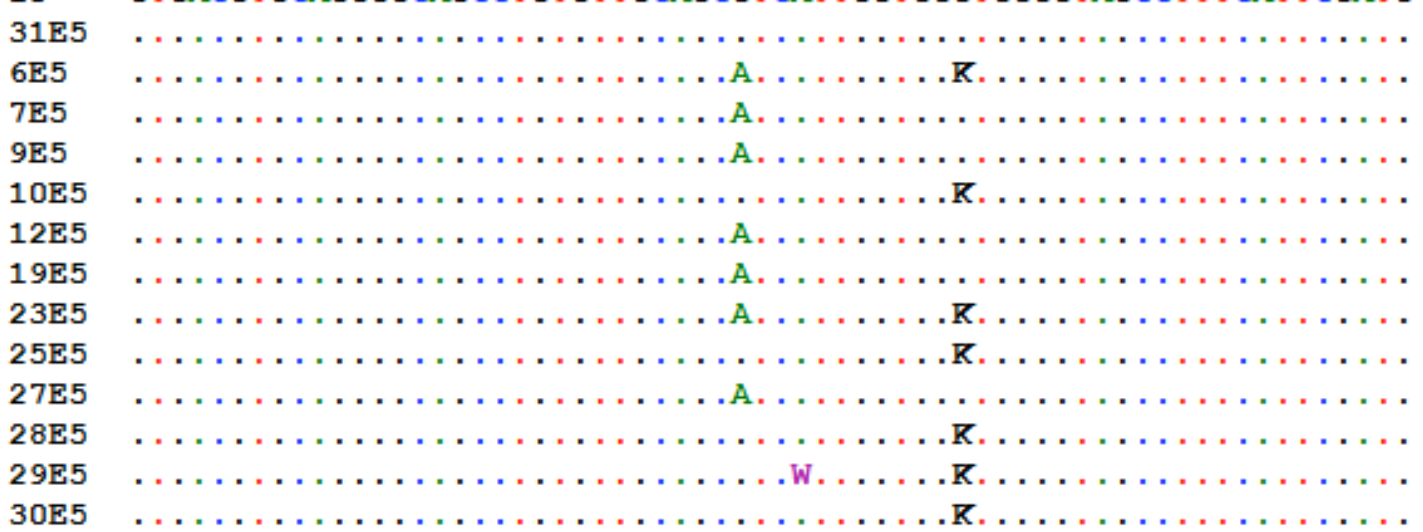

Figure 1. Sequence images of 13 point mutations in intron 4 and 5 in $D J-1$ gene. A) 10 heterozygous mutations in intron 4; B) 2 heterozygous mutations and 1 homozygous mutation in intron 5 . 
The two heterozygous mutations that alter amino acid (Ala86Glu and Gly95Leu) found in one individual comparing with the wild type sequence (see Table 3 and Figure 2). Although, no other sequence alterations or deletion or duplication were detected, these mutations predicted to result in a loss of functional protein. Recently, mutations in $D J-1$ were identified in consanguineous Dutch and Italian kindreds. In the Dutch kindred, a $14 \mathrm{~kb}$ genomic deletion removed the promoter region and the first five exons (D125). In the Italian kindred, a highly conserved amino acid (leucine) was altered to proline (L166P). Both mutations showed complete segregation with disease in homozygous or heterozygous individuals, suggesting that loss of function of $D J-1$ is pathogenic (Bonifati et al., 2003). In addition, the Ala167Ala mutation was previously identified in a PD patient (homozygote carrier) from the United Kingdom and in a patient from a North
American material with Caucasian/Hispanic origin (heterozygote carrier) (Abou-Sleiman et al., 2006). This is the first report on $D J-1$ mutation identified in Vietnamese PD patients. This is the first report on $D J-1$ mutation identified in Vietnamese PD patients. Therefore, there are several possibilities concerning to the mechanism of these alter mutations. Several possibilities have been suggested for mutations including alterations of mRNA stability, secondary structure, transcriptional activity, or changes in protein synthesis, folding, levels, turnover and/or function. Moreover, the unidentified genetic pathways and differences in environmental factors might contribute to the phenotypic variability among PD patients. We report here all the changes found in this series of PD cases and controls. The pathogenic role of these mutations will become clearer as other data emerge from other populations and genes in our further study.

$\underline{A}$

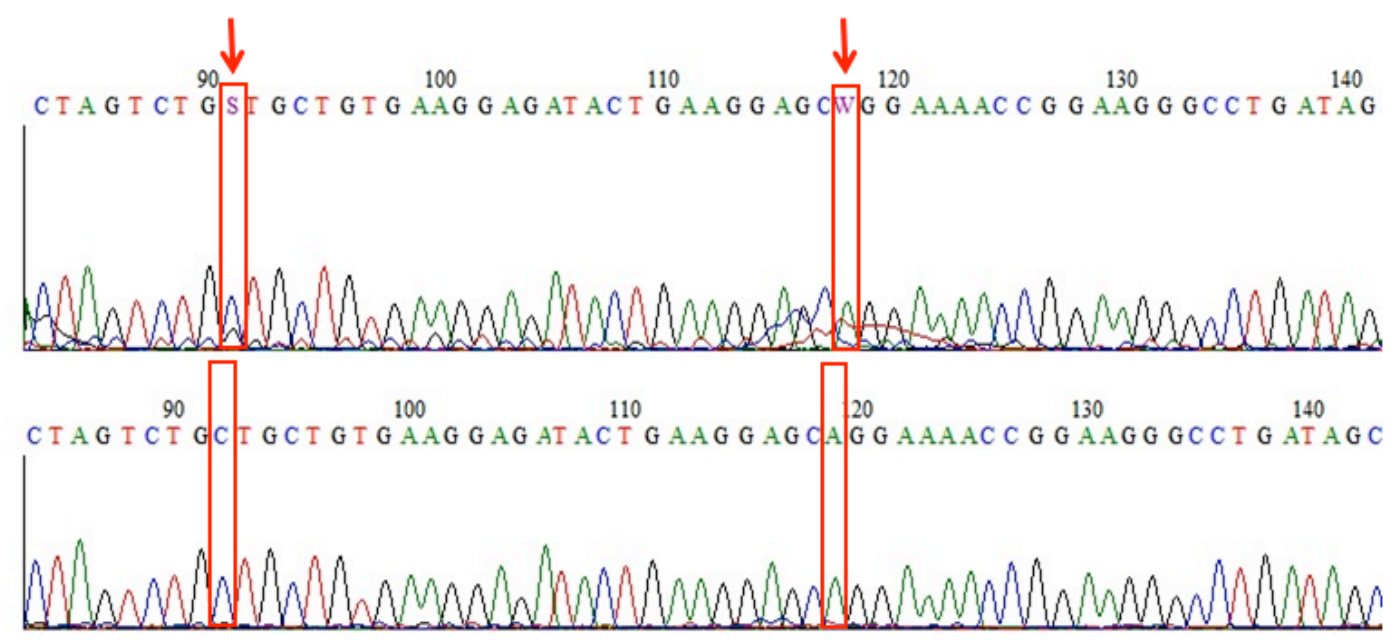

Figure 2. Results from automated capillary sequencing of exon 5 in $D J-1$ including the Ala86Glu (c.257C>G; p.A86G) and Gly95Leu (c.284A>T; p.G95L) mutations using a forward sequencing primer. A) A heterozygous mutation carrier ; B) A homozygous wild type carrier.

\section{CONCLUSION}

In conclusion, we identified the presence of 18 mutations in the exon 5 and introns 4 and 5 of $D J-1$ gene. Although our hypothesis that these mutations would contribute to disease, the nonsynonymous and uncertain significance of two variant mutations (c. $257 \mathrm{C}>\mathrm{G}$; p.A86G and c. $284 \mathrm{~A}>\mathrm{T}$; p.G95L) in $D J$ 1 gene was no parameter for defining fast-evolving and slow-evolving protein-coding genes regarding pathogenicity. To clarify the pathogenic associations of $D J-1$ gene with $\mathrm{PD}$, further studies focusing on large genetic cohort and epigenetic inactivation mechanisms involving these genes are required in PD patients and in their relatives with suspected symptoms.

Acknowledgements: This research was funded by Institute of Genome Research, Vietnam Academy of Science and Technology.

\section{REFERENCES}

Abou-Sleiman PM, Muqit MM, McDonald NQ, Yang YX, Gandhi S, Healy DG, Harvey K, Harvey RJ, Deas E, 
Bhatia K, Quinn N, Lees A, Latchman DS, Wood NW (2006) A heterozygous effect for PINK1 mutations in Parkinson's disease? Ann Neurol 60: 414-9.

Berget SM (1995) Exon recognition in vertebrate splicing. J Biol Chem 270: 2411-4.

Bjorkblom B, Maple-Grodem J, Puno MR, Odell M, Larsen JP, Moller SG (2014) Reactive oxygen speciesmediated DJ-1 monomerization modulates intracellular trafficking involving karyopherin beta2. Mol Cell Biol 34: 3024-40.

Bonifati V, Rizzu P, van Baren MJ, Schaap O, Breedveld GJ, Krieger E, Dekker MC, Squitieri F, Ibanez P, Joosse M, van Dongen JW, Vanacore N, van Swieten JC, Brice A, Meco G, van Duijn CM, Oostra BA, Heutink P (2003) Mutations in the DJ-1 gene associated with autosomal recessive early-onset parkinsonism. Science 299: 256-9.

Chen Y, Gao C, Sun Q, Pan H, Huang P, Ding J, Chen S (2017) MicroRNA-4639 Is a Regulator of DJ-1 Expression and a Potential Early Diagnostic Marker for Parkinson's Disease. Front Aging Neurosci 9: 232.

Clarke CE, Patel S, Ives N, Rick CE, Woolley R, Wheatley K, Walker MF, Zhu S, Kandiyali R, Yao G, Sackley CM (2016) Clinical effectiveness and costeffectiveness of physiotherapy and occupational therapy versus no therapy in mild to moderate Parkinson's disease: a large pragmatic randomised controlled trial (PD REHAB). Health Technol Assess 20: 1-96.

Healy DG, Abou-Sleiman PM, Valente EM, Gilks WP, Bhatia K, Quinn N, Lees AJ, Wood NW (2004) DJ-1 mutations in Parkinson's disease. J Neurol Neurosurg Psychiatry 75: 144-5.

Honbou K, Suzuki NN, Horiuchi M, Niki T, Taira T, Ariga H, Inagaki F (2003) The crystal structure of DJ-1, a protein related to male fertility and Parkinson's disease. $J$ Biol Chem 278: 31380-4.

Kefalopoulou Z, Politis M, Piccini P, Mencacci N, Bhatia $\mathrm{K}$, Jahanshahi M, Widner H, Rehncrona S, Brundin P, Bjorklund A, Lindvall O, Limousin P, Quinn N, Foltynie T (2014) Long-term clinical outcome of fetal cell transplantation for Parkinson disease: two case reports. JAMA Neurol 71: 83-7.

Klein C, Westenberger A (2012) Genetics of Parkinson's disease. Cold Spring Harb Perspect Med 2: a008888.

Lin J, Prahlad J, Wilson MA (2012) Conservation of oxidative protein stabilization in an insect homologue of parkinsonism-associated protein DJ-1. Biochemistry 51: 3799-807.
Malgieri G, Eliezer D (2008) Structural effects of Parkinson's disease linked DJ-1 mutations. Protein Sci 17: 855-68.

Matsuda N, Kimura M, Queliconi BB, Kojima W, Mishima M, Takagi K, Koyano F, Yamano K, Mizushima T, Ito Y, Tanaka K (2017) Parkinson's disease-related DJ-1 functions in thiol quality control against aldehyde attack in vitro. Sci Rep 7: 12816.

Mitsumoto A, Nakagawa Y (2001) DJ-1 is an indicator for endogenous reactive oxygen species elicited by endotoxin. Free Radic Res 35: 885-93.

Rakshit H, Rathi N, Roy D (2014) Construction and analysis of the protein-protein interaction networks based on gene expression profiles of Parkinson's disease. PLoS One 9: e103047.

Saito Y, Miyasaka T, Hatsuta H, Takahashi-Niki K, Hayashi K, Mita Y, Kusano-Arai O, Iwanari H, Ariga H, Hamakubo T, Yoshida Y, Niki E, Murayama S, Ihara Y, Noguchi N (2014) Immunostaining of oxidized DJ-1 in human and mouse brains. J Neuropathol Exp Neurol 73: 714-28.

Sidransky E, Nalls MA, Aasly JO, Aharon-Peretz J, Annesi G, Barbosa ER, Bar-Shira A, Berg D, Bras J, Brice A, Chen CM, Clark LN, Condroyer C, De Marco EV, Durr A, Eblan MJ, Fahn S, Farrer MJ, Fung HC, Gan-Or Z, Gasser T, Gershoni-Baruch R, Giladi N, Griffith A, Gurevich T, Januario C, Kropp P, Lang AE, Lee-Chen GJ, Lesage S, Marder K, Mata IF, Mirelman A, Mitsui J, Mizuta I, Nicoletti G, Oliveira C, Ottman R, Orr-Urtreger A, Pereira LV, Quattrone A, Rogaeva E, Rolfs A, Rosenbaum H, Rozenberg R, Samii A, Samaddar T, Schulte C, Sharma M, Singleton A, Spitz M, Tan EK, Tayebi N, Toda T, Troiano AR, Tsuji S, Wittstock M, Wolfsberg TG, Wu YR, Zabetian CP, Zhao Y, Ziegler SG (2009) Multicenter analysis of glucocerebrosidase mutations in Parkinson's disease. $N$ Engl J Med 361: 1651-61.

Yanagida T, Tsushima J, Kitamura Y, Yanagisawa D, Takata K, Shibaike T, Yamamoto A, Taniguchi T, Yasui $\mathrm{H}$, Taira T, Morikawa S, Inubushi T, Tooyama I, Ariga $\mathrm{H}$ (2009) Oxidative stress induction of DJ-1 protein in reactive astrocytes scavenges free radicals and reduces cell injury. Oxid Med Cell Longev 2: 36-42.

Zhang L, Shimoji M, Thomas B, Moore DJ, Yu SW, Marupudi NI, Torp R, Torgner IA, Ottersen OP, Dawson TM, Dawson VL (2005) Mitochondrial localization of the Parkinson's disease related protein DJ-1: implications for pathogenesis. Hum Mol Genet 14: 2063-73. 


\title{
PHÂN TÍCH ĐỘT BIẾN CỦA GEN DJ-1 Ở BỆNH NHÂN PARKINSON VIỆT NAM
}

\author{
Hồ Trường Giang ${ }^{1}$, Nguyễn Đức Hiếu ${ }^{2}$, Nguyễn Thị Hoài Thu ${ }^{2}$, Vũ Xuân Nghĩa $^{3}$, Võ Thị Bích Thủy ${ }^{2}$ \\ ${ }^{1}$ Học viện Quân y, Bộ Quốc phòng \\ ${ }^{2}$ Viện Nghiên cứu hệ Gen, Viện Hàn lâm Khoa học và Công nghệ Việt Nam
}

\section{TÓM TẮT}

Bệnh Parkinson (PD) là một tình trạng thoái hóa của thần kinh trung ương với các nguyên nhân chưa được xác định chắc chắn nhưng chủ yếu tác động đến người già. Rối loạn vận động là đặc trưng của bệnh, cứng cơ, run, chuyển động chậm chạp làm ảnh hưởng đến cuộc sống hàng ngày của người bệnh. Một số lượng lớn các đột biến trên các gen có liên quan đến bệnh Parkinson $(\mathrm{PD})$ đã được tìm thấy. Gen $D J-1$, là một gen thuộc nhóm gen PARK, được xác định là liên quan đến bệnh PD. Việc phân tích tần suất đột biến của gen $D J-1$ ở bệnh nhân $\mathrm{PD}$ Việt Nam là cần thiết để làm rõ các mối liên hệ gây bệnh của gen $D J-1$ với bệnh Parkinson và tìm hiểu về cơ chế gây bệnh và cơ chế di truyền của $\mathrm{PD}$. Trong nghiên cứu này, mẫu DNA tổng số được tách chiết từ máu ngoại vi của 30 bệnh nhân $\mathrm{PD}$ (ở độ tuổi $64.11 \pm 7.31$ ), 20 mẫu đối chứng, và giải trình tự bằng Sanger một vùng mã hoá của $D J-1$ (chứa intron 4 và 5 , và exon 5 ). Kết quả chúng tôi đã sàng lọc được 13 điểm đột biến dị hợp tử hoặc đồng hợp tử xuất hiện trong intron 4 và 5 . Có một bệnh nhân khởi phát bệnh muộn (LOPD) mang đột biến đồng hợp tử duy nhất ở intron 5 (IVS5+31G $>A$ ), các bệnh nhân còn lại đều mang đột biến dị hợp tử, nhưng tất cả các đột biến đều không có ý nghĩa. Điều đáng chú ý là cả hai đột biến Ala86Glu và Gly95Leu trên exon 5 đều xuất hiện ở một bệnh nhân $\mathrm{PD}$ và điều này có thể dẫn đến một sự thay đổi của protein chức năng. Phân tích bằng tin sinh học hai đột biến trên cho thấy chúng đều là đột biến không đồng nhất và không chắc chắn, do vậy có thể chúng không có liên quan đến đột biến gây bệnh Parkinson. Trong tương lai, cần nghiên cứu thêm về vai trò của các đột biến mới ở các gen PARK khác có liên quan đến sinh bệnh học của các bệnh nhân mắc PD ở Việt Nam.

Từ khóa: Bệnh Parkinson, exon 5, gen DJ-1, PARK loci, giải trình tụ gen 